\title{
Anthropogenic contamination of Portuguese coastal waters during the bathing season: Assessment using caffeine as a chemical marker
}

\author{
Paula Paíga, Cristina Delerue-Matos* \\ REQUIMTE/LAQV, Instituto Superior de Engenharia do Porto, Politécnico do Porto, Rua Dr. António Bernardino de Almeida, 431, 4200-072 Porto, Portugal
}

\section{A R T I C L E I N F O}

\section{Keywords:}

Atlantic Ocean

Bathing season

Caffeine

Human pollution tracer

Solid phase extraction

UHPLC-ESI-MS/MS

\begin{abstract}
A B S T R A C T
Bathing water quality standards are based on international standards and legislations. However, in Europe, only the microbiological parameters are to be accomplished. Recent research has focused on chemical indicators that can determine human fecal contaminants in water. Therefore, the suitability of caffeine as a chemical marker of seawater pollution in the north Portuguese coastal area in the Atlantic Ocean during the bathing season was assessed in this study. The quality of water from the coasts of five cities was monitored. 101 seawater samples were collected from 14 beaches, and their water quality was classified as sufficient, good, and excellent. Caffeine was detected in all samples in concentration range of 18 to $525 \mathrm{ng} / \mathrm{L}$. The highest average concentration of caffeine was found in seawater samples collected in July from beaches classified as having sufficient water quality, which were located in cities with high population density and high tourist affluence.
\end{abstract}

Oceans and seas hold about $96.5 \%$ of the Earth's water. Although oceans cover two-thirds of the Earth's surface, they are easily vulnerable to human influences, e.g., overfishing, pollution from run-off, and dumping of waste from human activities (Boopathy, 2000). Sewage effluent from waste water treatment plants (WWTPs) is recognized as a major source of human pollution (Gaw et al., 2013) and is discharged into marine environments through coastal areas and through rivers receiving WWTP effluents (Benotti and Brownawell, 2007). Moreover, because of their location, coastal areas represent a major advantage as many economic activities may take place, including tourism, commercial ports, and harbors, thus making them more vulnerable to higher levels of pollution than other seawater samples (Loos et al., 2013).

Since the 1970s, the European Union (EU) has laid down rules to safeguard public health and bathing waters. The EU must inform the public about bathing water quality and beach management through bathing water profiles. These profiles contain information on the kind of pollution and sources that affect the quality of the bathing water and that pose a risk to bathers' health (EC, European Comission, 2015, European bathing water quality). The revised Bathing Water Directive of 2006 updated and simplified these rules. It requires the Member States to monitor and assess the bathing water quality. The requirements for award beaches and marine areas with a flag ["Sufficient (yellow flag)," "Good (green flag)," and "Excellent" (blue flag)] are: the accessibility, infrastructure, safety of beaches, environmental information and education, and water quality. The last parameter is a health factor and an important indicator of environmental quality (EC,
European Commission, 2006, Directive 2006/7/EC).

Concerning the management of bathing water quality, Escherichia coli (fecal coli bacteria) and Enterococcus intestinalis (streptococci) are indicator organisms used for predicting microbiological health risk and to obtain a high level of protection for beaches and marine areas. When "pollution" occurs, it means that there is presence of microbiological contamination or other organisms or waste affecting the quality of the bathing water, presenting a risk to bathers' health (EC, European Commission, 2006, Directive 2006/7/EC). McLella and Eren (2014) stated that the presence of $E$. coli and $E$. intestinalis in water is a strong indicator of sewage contamination. However, these analyses do not indicate the origin of the contaminants, i.e., whether it is animal or human origin (Glassmeyer et al., 2005). Suitable markers are therefore necessary to detect and locate the sources of water pollution (Ferreira and da Cunha, 2005). From all the markers investigated such as fecal sterol coprostanol [a fecal sterol produced in the digestive tract of humans by the microbial biohydrogenation of cholesterol (Leeming and Nichols, 1996)] and pharmaceuticals (Daneshvar et al., 2012; Andreu et al., 2016), the one that received the most attention in recent times is caffeine (Buerge et al., 2003; Ferreira and da Cunha, 2005; Peeler et al., 2006; Kurissery et al., 2012).

Caffeine is an ingredient in a variety of beverages (coffee, tea, and caffeinated soft drinks) and numerous food products (chocolate, pastries, and dairy desserts) (Ferreira, 2005). In the world, 90\% of the people consume daily at least one meal or beverage with caffeine in it (Buerge et al., 2003). The global average consumption of caffeine is 
estimated to be between 80 and $400 \mathrm{mg}$ per person per day (Gokulakrishnan et al., 2005). Buerge et al. (2003) mentioned that there are large differences among countries regarding the contribution of different food sources to total caffeine intake. Caffeine is also of further importance in pharmaceuticals. It enhances the effect of certain analgesics used for cough, cold, and headache. Caffeine is used as a cardiac, cerebral, and respiratory stimulant and as a diuretic (Buerge et al., 2003).

Caffeine is a very good tracer because its detection in the aquatic system indicates human waste source (Peeler et al., 2006). Caffeine concentration previously found in seawater samples and estuarine systems ranged from nanograms to micrograms per liter (Weigel et al., 2002; Benotti and Brownawell, 2007). The first study that reported the presence of caffeine in seawater samples was presented by Weigel et al. (2001). The authors mentioned a group of compounds that were not reported before in marine ecosystems, in which caffeine was included. In literature, caffeine was found in the North Sea of the United Kingdom, the Netherlands, Germany, Denmark, and Norway (Weigel et al., 2001; Weigel et al., 2002); in the Mediterranean Sea of Swiss midland region (Buerge et al., 2003); in the Hanalei Bay of Kauai in Hawaii (Knee et al., 2010); in the Atlantic Ocean of Costa da Caparica in Portugal (Neng and Nogueira, 2012) and of Todos os Santos Bay in Salvador of Brazil (Ferreira, 2005); in west coast of Vancouver Island in British Columbia (Verenitch and Mazumder, 2008); in the coastal watersheds in Canada (Comeau et al., 2008); in the Marina Bay of Singapore (Wu et al., 2008); in Oregon coastal region (Rodriguez del Rey et al., 2012); in the Biscayne Bay of Florida (Gardinali and Zhao, 2002); in South Florida coastal region (Singh et al., 2010); and in the Jamaica Bay of New York in the United States of America (Benotti and Brownawell, 2007).

As mentioned by Ribeiro et al. (2015), estuaries, rivers, and coastal areas are subjected to intensive anthropogenic pressure from a wide range of pollutants discharged into them. An increase in recreational activities during the sea bathing season has been coupled with an increase in the worries about the dangers of bathing in waters contaminated by sewage discharges.

Portugal is located in southwestern Europe and has an extended coastal area in the Atlantic Ocean. Most of the Portuguese population is settles in the coastal areas, where most of industrial, agricultural, and port activities are implemented. To the authors' knowledge, this is the first time that ca ffeine was used as an anthropogenic marker of human pollution in seawater samples collected from the Portuguese coastal area. A total of 101 seawater samples were collected during the bathing season (from the middle of June to the middle of September) in 2013, and quality of water from 14 beaches of four cities in the North (Vila do Conde, Matosinhos, Porto, Vila Nova de Gaia) and one city in the Center (Espinho) of Portugal was monitored. Therefore, our primary objective was to monitor the levels of caffeine in seawater samples, as a human pollution marker, collected from beaches classified as having sufficient, good, and excellent water quality. The secondary objective was to highlight the importance of including others parameters, such as caffeine, in the legislation of the Blue Flag Program.

Sampling frequency was determined by considering the bathing water quality. Thus, for excellent quality bathing water samples were collected only once a month; for good quality bathing water every 2 weeks; and for sufficient quality bathing water every week (EC, European Commission, 2006, Directive 2006/7/EC). Seawater samples were collected by the Portuguese Environment Agency (APA, Agência Portuguesa do Ambiente-Portuguese Environment Agency). The samples were directly collected from the sea, preferably away from the surf caused by the waves, where the depth reaches at least $1 \mathrm{~m}$ to avoid the presence of suspended sediments in the samples. The distance to the shore varies according to the beach type, although the main concern was to respect the 1-meter depth requirement (ISO 5667-3, 2012).

A total of 101 grab seawater samples were collected from the 14 beaches of five cities (Fig. 1). Two beaches in City 1 (Vila Nova do
Conde) (both beaches classified as excellent water quality), four beaches in City 2 (Matosinhos) (one beach classified as excellent, two beaches classified as good, and one beach classified as sufficient water qualities), two beaches in City 3 (Porto) (one beach classified as excellent and one beach classified as sufficient water quality), 3 beaches in City 4 (Vila Nova de Gaia) (two beaches classified as excellent and one beach classified as sufficient water qualities), and 3 beaches in City 5 (Espinho) (one beach classified as excellent, one beach classified as good, and one beach classified as sufficient water quality) were assessed (Table SM1, Supplementary material).

Microbiological determinations and the information on the studied beaches were supplied by the APA (APA, Agência Portuguesa do Ambiente-Portuguese Environment Agency) and are given in Table SM1 (Supplementary material). Information on the studied beaches was presented in the work of Lolić et al. (2015). It is noteworthy that seawater samples were collected at the same time for (a) microbiologic, (b) pharmaceutical (the study of Lolić et al. (2015)), and (c) caffeine (present study) analysis.

Amber glass bottles pre-rinsed with ultrapure water were used for sample collection. After reception in the laboratory, the seawater samples were filtered through $0.22-\mu \mathrm{m}$ nylon membrane filters (Fioroni Filters, Ingré, France).

Acetonitrile LC-MS grade was supplied by Biosolve (Valkenswaard, Netherland), methanol LC-MS Ultra CHROMASOLV ${ }^{\circledR}$ and formic acid 98\% PA-ACS were purchased from Sigma-Aldrich (Steinheim, Germany), and hydrochloric acid 37\% was obtained from Carlo Erba (Rodano, Italy). Ultrapure water (resistivity of $18.2 \mathrm{M} \Omega \cdot \mathrm{cm}$ ) was produced using a Simplicity 185 system (Millipore, Molsheim, France).

Caffeine and isotopically labeled standard (caffeine ${ }^{13} \mathrm{C}_{3}$, certified reference material, $1.0 \mathrm{mg} / \mathrm{mL}$ in methanol) were purchased from Sigma-Aldrich (Steinheim, Germany). Standard stock solutions of caffeine and caffeine ${ }^{13} \mathrm{C}_{3}$ at concentrations of $1 \mathrm{~g} / \mathrm{L}$ in methanol were prepared and stored in the dark at $-20^{\circ} \mathrm{C}$. Working standard solutions used to prepare the calibration and fortification standards were prepared in the initial mobile phase conditions.

All chromatographic solvents were filtered through a $0.22-\mu \mathrm{m}$ nylon membrane filter (Fioroni Filters, Ingré, France) using a vacuum pump (Dinko D-95, Barcelona, Spain) and degassed for $15 \mathrm{~min}$ in an ultrasonic bath (Sonorex Digital 10P, Bandelin DK 255P, Germany). Before chromatographic analysis, sample extracts were filtered through 0.22 $\mu \mathrm{m}$ PTFE syringe filters (Specanalitica, Carcavelos, Portugal). Solidphase extraction (SPE) cartridges (Strata-X; $200 \mathrm{mg}, 3 \mathrm{~mL}$ ) from Phenomenex (California, USA) were used for SPE.

Caffeine concentration in the collected seawater samples was performed following a procedure based on SPE and liquid chromatography (LC) coupled to tandem mass spectrometry (MS/MS).

SPE procedure was adopted as described in the work of Paíga et al. (2015). Seawater samples ( $\mathrm{pH} 2$, adjusted with hydrochloric acid) were preconcentrated onto Strata-X SPE cartridges $(200 \mathrm{mg}, 3 \mathrm{~mL}$ ), which were previously preconditioned with $5 \mathrm{~mL}$ methanol, followed by $5 \mathrm{~mL}$ ultrapure water and $5 \mathrm{~mL}$ ultrapure water at $\mathrm{pH} 2$, using a vacuum system manifold (Chromabond, Düren, Germany). After loading $500 \mathrm{~mL}$ seawater samples, cartridges were rinsed with $5 \mathrm{~mL}$ ultrapure water and dried under vacuum for $60 \mathrm{~min}$ to remove excess water. After elution with $10 \mathrm{~mL}$ methanol, the extracts were evaporated under a gentle stream of nitrogen and further reconstituted to a final volume of $1 \mathrm{~mL}$ of the initial mobile phase conditions. The achieved enrichment factor was 500 . Finally, $10 \mu \mathrm{L}$ of caffeine ${ }^{13} \mathrm{C}_{3}$ standard was added to obtain a final concentration of $200 \mu \mathrm{g} / \mathrm{L}$.

Quantification of caffeine was performed using a Nexera Ultra-High Performance Liquid Chromatography system (Shimadzu Corporation, Kyoto, Japan) equipped with two solvent delivery modules, a degasser, an autosampler, a column oven, and an LC-MS/MS detector (LCMS8030) with an electrospray ionization source.

Identification and quantification were performed under Multiple Reaction Monitoring (MRM), which recorded the transitions between 


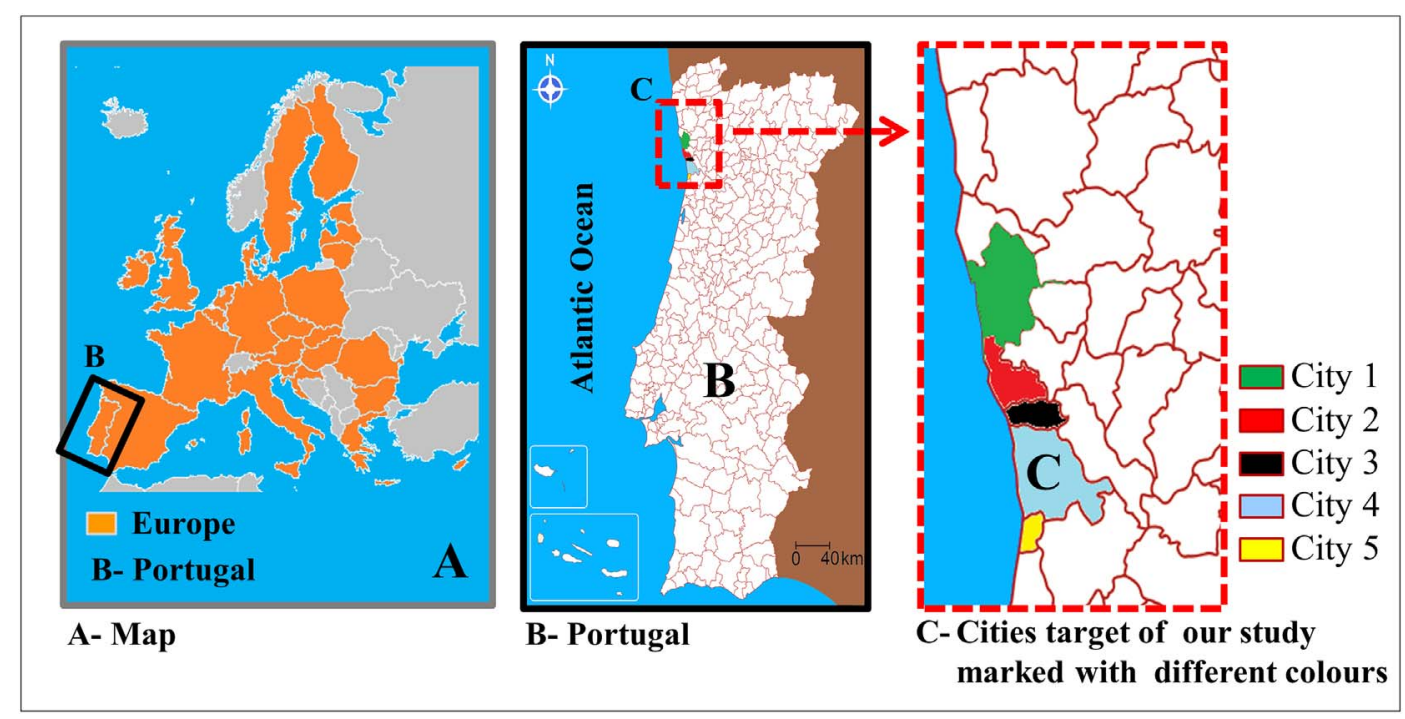

Fig. 1. Geographical map of the study cities (City 1-Vila do Conde, City 2-Matosinhos, City 3-Porto, City 4-Vila Nova de Gaia, and City 5-Espinho).

the precursor ion and the two most abundant product ions for caffeine and the most abundant product for caffeine ${ }^{13} \mathrm{C}_{3}$. The optimization of the precursor and the product ions were made by the direct injection of each standard at a concentration of $100 \mathrm{mg} / \mathrm{L}$ (Table SM2, Supplementary material). Caffeine and caffeine ${ }^{13} \mathrm{C}_{3}$ were analyzed in positive ionization mode.

Source-dependent parameters were optimized by the directly injecting a standard mixture solution of $10 \mathrm{mg} / \mathrm{L}$. Desolvation line and heat block temperatures were set at $300{ }^{\circ} \mathrm{C}$ and $425^{\circ} \mathrm{C}$; interface voltage at $5.0 \mathrm{kV}$; and nebulizing gas and drying gas (nitrogen) at a flow rate of 2.6 and $15 \mathrm{~L} / \mathrm{min}$, respectively. Argon was used as a collision-induced dissociation gas at a pressure of $230 \mathrm{kPa}$. After the chromatographic conditions were optimized, and separation was carried out in a Cortecs $^{\mathrm{TM}}$ UPLC $^{\circledast} \mathrm{C} 18+$ column $(100 \times 2.1 \mathrm{~mm}$ i.d.; $1.6 \mu \mathrm{m}$ particle size) from Waters (Milford, Massachusets, USA). The eluents of the mobile phase were $0.1 \%$ formic acid in ultrapure water (eluent $\mathrm{A}$ ) and acetonitrile (Eluent B) at a flow rate of $0.3 \mathrm{~mL} / \mathrm{min}$. Gradient elution started with $10 \%$ of eluent $\mathrm{B}$, increasing to $100 \% \mathrm{~B}$ in $2 \mathrm{~min}$, maintained $100 \%$ B for $0.5 \mathrm{~min}$, and returned to initial conditions within $1 \mathrm{~min}$. The column was re-equilibrated for $2.5 \mathrm{~min}$ before the next injection. The autosampler was operated at $4{ }^{\circ} \mathrm{C}$. The injection volume was $5 \mu \mathrm{L}$, the column temperature was kept at $30^{\circ} \mathrm{C}$, and a dwell time of $100 \mathrm{~ms}$ was used. LabSolutions software (version 5.80, Shimadzu) was used for system control and data processing. The optimized ionization mode, fragmentation voltages, collision energies, and chromatographic retention times of each analyte are summarized in Table SM2 (Supplementary material).

After the conditions for the extraction and the analysis of caffeine in seawater samples were defined, the validation of the method was carried out. Linearity, method detection limits (MDLs), method quantification limits (MQLs), precision as repeatability [expressed as relative standard deviation (\%RSD)], recovery and matrix effects (ME) were studied. Linear regression analysis was established by setting calibration curves in the solvent and in the seawater samples (matrix-matched calibration curve) using standards with concentrations ranging from 10 to $1000 \mu \mathrm{g} / \mathrm{L}$ (10-point calibration standards). The linearity was qualified by the linear correlation coefficient $\left(\mathrm{r}^{2}\right)$. The calibration curves obtained for both transitions of caffeine were linear with $r^{2}>$ 0.9992 in all the cases (in solvent and matrix-matched calibration curves). Using the chromatographic program, the retention time of caffeine was determined as $2.181 \mathrm{~min}(n=10, \mathrm{RSD}=0.162 \%)$ and that of caffeine ${ }^{13} \mathrm{C}_{3}$ determined as $2.182 \mathrm{~min} \quad(n=10$, RSD $=0.0835 \%$ ). Quantification of the analytes was performed by the internal standard approach.
Accuracy of the method was assessed by performing recovery experiments in seawater samples. Recovery was calculated by comparing the MRM peak area for samples spiked prior to SPE (pre-spiked sample), with the MRM peak area for samples spiked after SPE (postspiked sample) (Paíga and Delerue-Matos, 2016). Extraction recoveries for caffeine were determined $(n=2)$ at two fortification levels, 0.2 and $0.5 \mu \mathrm{g}_{\text {caffeine }} / \mathrm{L}_{\text {sample. }}$. In both fortifications, precision limit, expressed as RSD, was lower than $2.0 \%$, indicating the good precision of the method developed. Recoveries obtained were with $104 \%$ (RSD, 1.77\%) for the lower fortification level and $95.8 \%$ (RSD, 0.837\%) for the highest fortification level.

Method precision was determined by Intra- and Inter-day analysis (\%RSD). Three standards with final concentrations of 100, 250, and $1000 \mu \mathrm{g} / \mathrm{L}$ were used and 12 successive injections in 1 day for 3 consecutive days (triplicate injection) was performed. The results were $4.31 \%, 3.57 \%$, and $1.94 \%$ in Intra-day analysis and $8.51 \%, 8.25 \%$, and $5.65 \%$ in Inter-day analysis for standards of 100,250 , and $1000 \mu \mathrm{g} / \mathrm{L}$, respectively.

The sensitivity limits (MDLs and MQLs) were determined using real seawater samples. The results obtained were 0.890 and $1.02 \mathrm{ng} / \mathrm{L}$ for MDL and MQL respectively.

The ME was evaluated in seawater samples, and the obtained result was expressed as percentage suppression or enhancement [Eq. (1) (Gros et al., 2012)]. The slope of the matrix-matched calibration curve was compared with the slope of the calibration curve prepared in the solvent (initial mobile phase conditions). A value of zero indicates that there is no ME, a positive value indicates that there is an ion enhancement signal, and a negative value indicates an ion suppression signal. The matrix effect obtained for seawater samples was $17.1 \%$ of ion suppression.

Signal supression $(\%)=\left(\frac{\text { slope }_{\text {matrix-matched }}}{\text { slope }_{\text {solvent }}}-1\right) \times 100$

The identification and confirmation criterion for the analysis of the caffeine was performed according to the European Commission Decision 2002/657/EC (EC, European Commission, 2002, Directive $2002 / 657 / \mathrm{EC})$. To confirm the presence of caffeine, the retention time ( $2.5 \%$ tolerance) and relationship between the two transitions (difference of $<20 \%$ ) were compared. The MRM transition with the highest intensity was used for quantification, while the second transition was used for confirmation.

Five cities in the north and center of Portugal were studied, and the water quality at 14 beaches was monitoring during the seasonal bathing 
period. The seawater samples collected from each beach and the corresponding city are given in Table SM1 (Supplementary material). In a favorable strategic location, Portugal cannot be dissociated from the ocean that embraces it and on which the country depends. Because most tourists are motivated by the ocean and considering the growth of activities and companies linked to this natural resource, the trend for active vacations justifies the increasing demand for water sports activities, including surfing (Reis and Jorge, 2012) and tourist trips by boats. However, one must also consider the increase in the number of tourists on the beaches (Loos et al., 2013; Nödler et al., 2014). The location, population density, area, and recreational activities in the studied cities are described in the following paragraphs.

Cities with the highest population density were cities 2 and 3, both located in the north of Portugal. These cities have influences of (i) industries, (ii) discharge from WWTPs of the region, (iii) Portuguese harbor (Leixões harbor), and (iv) tourism. The second largest Portuguese artificial seaport, Porto de Leixões, is situated in Matosinhos (City 2), and Porto (City 3) was named the European Best Destination in 2014 for the second time (the first time that Porto was considered the "European Best Destination" was in 2012) according to a survey by the European Consumers Choice Organization, based in Brussels (Tourism in Portugal, n.d., www.travelweekly.com/EuropeTravel/Insights/Portugal-makes-a-tourism-comeback). Porto and Matosinhos share a large urban beach for surfing, which is the only Portuguese beach that is accessible by subway (Surf Today, n.d., www.surfertoday.com/travel/12411-the-truth-about-surfing-inportugals-northern-coast). The beaches in Matosinhos city are a very popular spot for beginners and have a large number of surf schools. According to the National Institute of Statistic, in 2013, the port Porto de Leixões hosted 67 cruise ships with 45,593 passengers and 24,000 crew members (INE, 2013). Alygizakis et al. (2016) mentioned that passenger ships with strong activity may also be an important source of contamination.
It could be observed in Table 1 that City 4 is the city with more habitants (302295) but is also a city with the lowest population density because of elevation from sea level $\left(168.46 \mathrm{~km}^{2}\right)$.

The discharge of effluents from the WWTP that was constructed for the population that lives far from the coastal areas has less influence on the coastal area water quality because its effluents are diluted during the river course.

Of all the studied towns, Cities 1, 4, and 5 had lower population densities, with City 1 having the lowest. Cities at higher elevation (Cities 1 and 4), as observed in Fig. 1 and Table 1, were the cities where the population is more dispersed and the average concentration of caffeine detected was lower (Table 1). It should be noted that City 5 has a small area but has also less population, and the influence of pollution in the coastal area was lower when compared with the others cities with small areas (Table 1).

Regardless of the water quality, in our study, caffeine was detected in all evaluated samples, with a concentration in the range of 18.0 to 525 ng/L. Moreover, Weigel et al. (2002, 2004), Gardinali and Zhao (2002), Peeler et al. (2006), Wu et al. (2008), Munaron et al. (2012), Loos et al. (2013), and Alygizakis et al. (2016) reported $100 \%$ frequency of caffeine in the samples in their studies. Furthermore, Loos et al. (2013) and Alygizakis et al. (2016) mentioned in their works that caffeine was one of the studied compounds with the highest concentration. Thus, it is of utmost important to monitor and evaluate the concentrations of caffeine in the environment.

The levels of caffeine found in the present study are shown in Fig. 2. The major slice in the pie chart showing all water qualities is represented by caffeine concentration of $<50 \mathrm{ng} / \mathrm{L}$, with $57.1 \%$, $74.1 \%$, and $38.1 \%$ of the samples showing excellent, good, and sufficient water qualities. The first and second slice cover $>90 \%$ of the volume in the pie chart for the samples collected from beaches classified as having excellent (92.9\%) and good (93.5\%) water qualities, and $61.9 \%$ for samples collected from the beaches classified as

Table 1

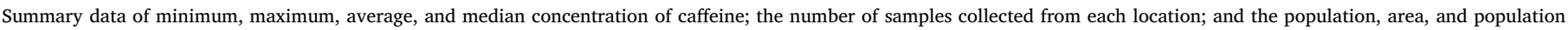
density of the study cities.

\begin{tabular}{|c|c|c|c|c|c|c|c|c|c|}
\hline Parameter target of the study & & Minimum & Maximum & Average & Median & $\mathrm{n}$ & $\begin{array}{l}\text { Population }{ }^{\mathrm{a}} \\
\text { Habitants }\end{array}$ & $\begin{array}{l}\text { Area }^{\mathrm{a}} \\
\mathrm{km}^{2}\end{array}$ & $\begin{array}{l}\text { Population }^{\mathrm{a}} \\
\text { Density } \\
\text { Habitants } / \mathrm{km}^{2}\end{array}$ \\
\hline \multirow[t]{3}{*}{ Classification water quality } & Excellent & 21.4 & 205 & 54.9 & 46.3 & 28 & & & \\
\hline & Good & 21.5 & 336 & 57.4 & 41.9 & 31 & & & \\
\hline & Sufficient & 18.0 & 525 & 116 & 68.1 & 42 & & & \\
\hline \multirow[t]{14}{*}{ Beach } & Beach 1 & 36.1 & 95.9 & 59.1 & 52.2 & 4 & & & \\
\hline & Beach 2 & 29.6 & 50.0 & 38.8 & 37.8 & 4 & & & \\
\hline & Beach 3 & 40.7 & 77.9 & 55.1 & 50.9 & 4 & & & \\
\hline & Beach 4 & 26.4 & 128 & 61.5 & 45.6 & 4 & & & \\
\hline & Beach 5 & 23.2 & 205 & 78.2 & 42.7 & 4 & & & \\
\hline & Beach 6 & 21.4 & 51.2 & 33.1 & 29.8 & 4 & & & \\
\hline & Beach 7 & 29.8 & 80.1 & 58.5 & 62.0 & 4 & & & \\
\hline & Beach 8 & 24.6 & 92.9 & 46.5 & 35.4 & 8 & & & \\
\hline & Beach 9 & 35.8 & 336 & 103 & 60.1 & 8 & & & \\
\hline & Beach 10 & 21.5 & 49.3 & 37.1 & 36.5 & 8 & & & \\
\hline & Beach 11 & 25.7 & 69.8 & 41.7 & 36.2 & 7 & & & \\
\hline & Beach 12 & 24.0 & 481 & 156 & 95.5 & 14 & & & \\
\hline & Beach 13 & 32.0 & 525 & 136 & 115 & 14 & & & \\
\hline & Beach 14 & 18.0 & 264 & 54.4 & 33.8 & 14 & & & \\
\hline \multirow[t]{4}{*}{ Month } & June & 24.0 & 192 & 69.5 & 59.1 & 24 & & & \\
\hline & July & 21.4 & 525 & 86.8 & 47.0 & 40 & & & \\
\hline & August & 18.0 & 262 & 77.1 & 47.0 & 27 & & & \\
\hline & September & 23.3 & 167 & 61.8 & 33.3 & 10 & & & \\
\hline \multirow[t]{5}{*}{ City } & City 1 & 29.6 & 95.9 & 48.9 & 43.7 & 8 & 79,533 & 149.03 & 530 \\
\hline & City 2 & 24.0 & 481 & 106 & 63.4 & 34 & 175,478 & 62.42 & 2800 \\
\hline & City 3 & 26.4 & 525 & 120 & 104 & 18 & 237,591 & 41.42 & 5736 \\
\hline & City 4 & 21.4 & 205 & 46.4 & 31.7 & 16 & 302,295 & 168.46 & 1800 \\
\hline & City 5 & 18.0 & 264 & 51.5 & 36.2 & 25 & 31,786 & 21.06 & 1600 \\
\hline
\end{tabular}

n-Number of samples collected

${ }^{a}$ Values in 2011. 


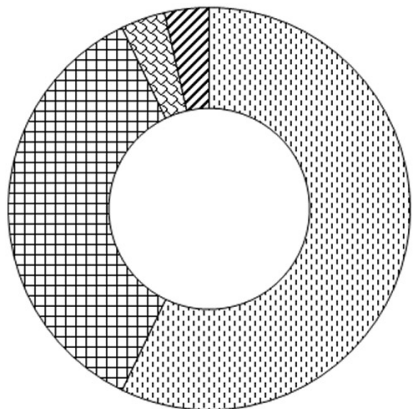

Excellent water quality

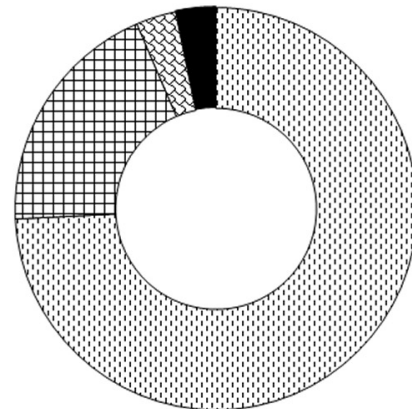

Good water quality

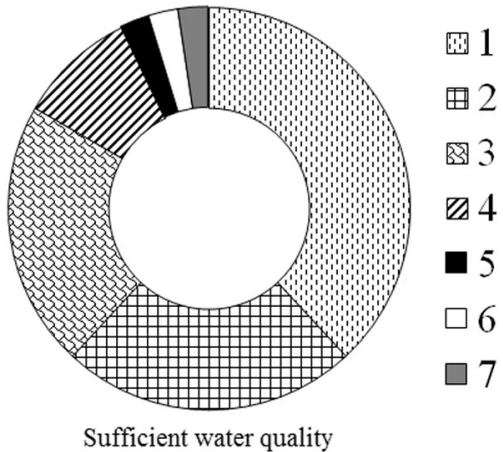

Sufficient water quality

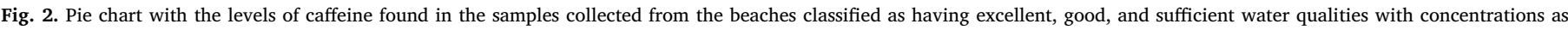

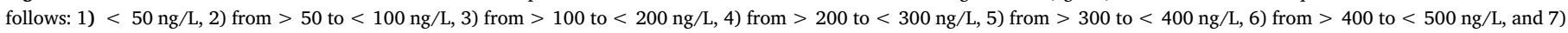
from $>500$ to $<600 \mathrm{ng} / \mathrm{L}$.

having sufficient water quality. For concentrations higher than $100 \mathrm{ng} /$ $\mathrm{L}$, it was observed that caffeine was found in more samples collected from beaches classified as having sufficient water quality (38.1\%) when compared with the remaining classifications $(7.1 \%$ for excellent and $6.5 \%$ for good water qualities) (Fig. 2).

The levels of caffeine found in the samples collected (i) in each classification of the water quality, (ii) from each beach, (iii) in each month of the bathing season, and (iv) from each city are shown in Table 1 (minimum, maximum, average, and median) and in the boxand-whisker plots presented in the Fig. 3.
Data of caffeine concentrations expressed in ng/L and the corresponding microbiological results were compared (Table SM2, Supplementary material). For the majority of the results, it was observed that the quality of water decreases as the level of caffeine in the analyzed samples increases, and the same profile was observed in the microbiological analysis. Sauvé et al. (2012) mentioned in their study that caffeine concentrations were relatively well correlated to fecal coliforms and could potentially be used as a chemical indicator of the level of contamination from sanitary sources. Therefore, the Blue Flag Program of beaches should include not only microbiological
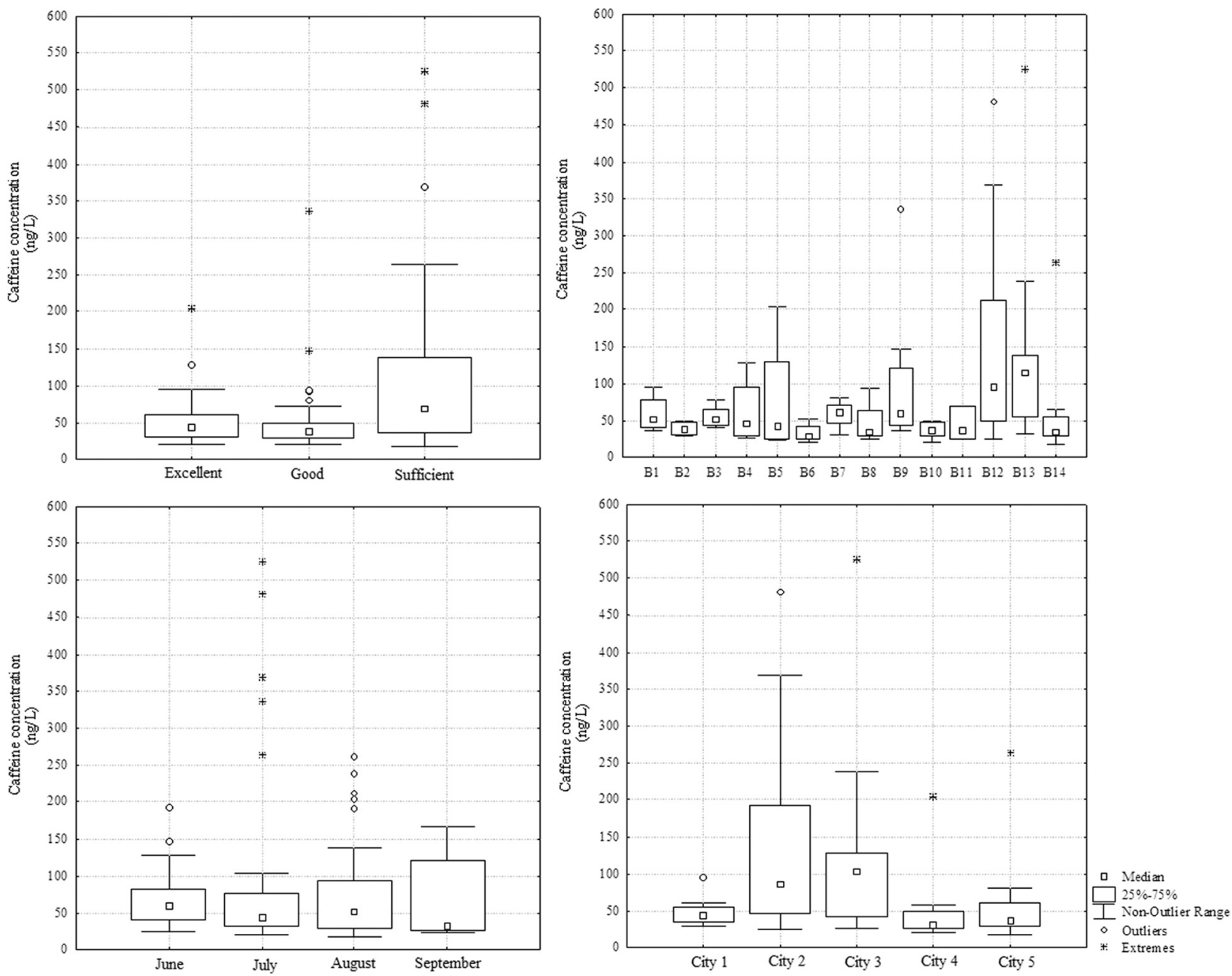

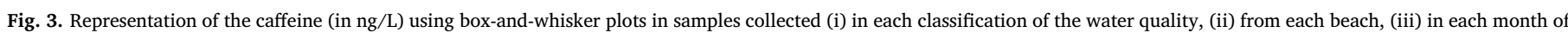
the bathing season, and (iv) in each city. 
Table 2

Locations of the sampling, concentrations of caffeine, and year of the publishing of works reporting caffeine concentrations in seawater samples by the scientific community.

\begin{tabular}{|c|c|c|c|}
\hline Location sea, ocean, marine, bay & Country & Concentration (ng/L) & References \\
\hline North Sea & German Bight & 2 & (Weigel et al., 2001) \\
\hline North Sea & $\begin{array}{l}\text { Norway, Denmark, Germany, Netherland, United } \\
\text { Kingdom }\end{array}$ & 2 to 16 & (Weigel et al., 2002) \\
\hline Miami Beach Marine, Biscayne Bay & Florida, United States of America & $<$ MDL to 11.9 & $\begin{array}{l}\text { (Gardinali and Zhao, } \\
\text { 2002) }\end{array}$ \\
\hline Boston Harbor and Massachusetts Bay & United States of America & $\begin{array}{l}5.2 \text { to } 71 \text { (Massachusetts bay) } \\
140 \text { to } 1600 \text { (Boston Harbon) }\end{array}$ & (Siegener and Chen, 2002) \\
\hline Mediterranean Sea & Southern Spain & $<$ MDL to 5 & (Buerge et al., 2003) \\
\hline $\begin{array}{l}\text { North Atlantic/Artic Ocean, Ocean inlet; ocean (10 km from } \\
\text { coastline) Tromsø-Sound }\end{array}$ & Norway & $\begin{array}{l}17 \text { to } 87 \text { (Ocean inlet) } \\
7 \text { to } 9 \text { (ocean ( } 10 \mathrm{~km} \text { from } \\
\text { coastline)) }\end{array}$ & (Weigel et al., 2004) \\
\hline Enclosed Lagoon Sarasota Bay & Florida United States of America & $<0.5$ to 166 & (Peeler et al., 2006) \\
\hline Jamaica Bay & New York, United States of America & n.d. to up to $\sim 5000$ & $\begin{array}{l}\text { (Benotti and Brownawell, } \\
\text { 2007) }\end{array}$ \\
\hline Atlantic Ocean, watershed & South coast of Nova Scotia, Canada & n.d. to 1400 & (Comeau et al., 2008) \\
\hline $\begin{array}{l}\text { Pacific Ocean, west coast of Vancouver Island, British } \\
\text { Columbia }\end{array}$ & Canada & 4.5 to 149 & $\begin{array}{l}\text { (Verenitch and Mazumder, } \\
\text { 2008) }\end{array}$ \\
\hline Marine Bay, Rochor Canal & Singapore & 370 to 1350 & (Wu et al., 2008) \\
\hline Hanalei Bay & Kauai, Hawaii & n.d. to 10 & (Knee et al., 2010) \\
\hline Baltic Sea (Ahlbeck, Usedom) & Germany & 58 & (Nödler et al., 2010) \\
\hline Central bay of Stockholm & Sweden & 30 to 80 & (Magnér et al., 2010) \\
\hline Key Largo Harbor, and Looe Key, Florida & Florida, United States of America & $\begin{array}{l}5.7 \text { to } 52 \text { (Key Largo Harbor) } \\
\text { n.d. to } 29 \text { (Looe Key) }\end{array}$ & (Singh et al., 2010) \\
\hline $\begin{array}{l}\text { French Mediterranean coast from the Italian border to the } \\
\text { east to the Spanish border to the west }\end{array}$ & French Mediterranean coastal waters & 8 to 32 & (Munaron et al., 2012) \\
\hline Atlantic Ocean, Charleston Harbor of Charleston & South Carolina, United States of America & 19 & (Hedgespeth et al., 2012) \\
\hline Atlantic Ocean & Costa da Caparica, Portugal & $<\mathrm{MDL}$ & (Neng and Nogueira, \\
\hline Pacific Ocean, Oregon coastal waters & United States of America & $<$ MDL to 44.7 & $\begin{array}{l}\text { (Rodriguez del Rey et al., } \\
\text { 2012) }\end{array}$ \\
\hline $\begin{array}{l}\text { Adriatic Sea (Offshore from Venice at the Acqua Alta } \\
\text { oceanographic tower) }\end{array}$ & Italy & 82.0 to 366.9 & (Loos et al., 2013) \\
\hline Singapore's marine & Republic of Singapore & $<59$ to 655 & (Bayen et al., 2013) \\
\hline San Francisco Bay water & United States of America & 15.0 to 40.8 & (Klosterhaus et al., 2013) \\
\hline Coastal southwestern Taiwan & Taiwan & 1.24 to 16.9 & (Jiang et al., 2014) \\
\hline Baltic Sea (Germany) & Germany, Italy, Greece, Turkey, San Francisco, & Up to 677 (Baltic Sea) & (Nödler et al., 2014) \\
\hline Northern Adriatic Sea (Italy) & United States of America, Israel, and Spain & Up to 58 (Northern Adriatic Sea) & \\
\hline Venice, Italy & & Up to 1110 (Venice) & \\
\hline Aegean Sea and Dardanelles (Greece \& Turkey) & & Up to 3068 (Aegean & \\
\hline San Francisco Bay (USA) & & Sea \& Dardanelles) & \\
\hline Pacific Ocean (USA) & & Up to 96 (San Francisco Bay) & \\
\hline Mediterranean Sea (Israel) & & Up to 85 (Pacific Ocean) & \\
\hline \multirow[t]{2}{*}{ Balearic Sea (Spain) } & & Up to 118 (Mediterranean Sea) & \\
\hline & & Up to 8.4 (Balearic Sea) & \\
\hline San Francisco Bay and Southern California Bight & California & Up to 32 & (Alvarez et al., 2014) \\
\hline Barbados West Coast, tropical Caribbean & America & 100 to 500 & (Edwards et al., 2015) \\
\hline Offshore in Kuwait Bay and along the Gulf coastline & Kuwait & 40 to 370 & (Smith et al., 2015) \\
\hline Santos Bay (São Paulo, Brazil) & Brazilian coastal zone & 84.4 to 648.9 & (Pereira et al., 2016) \\
\hline Northeast Aegean Sea & Greece & Up to 522 & (Nödler et al., 2016) \\
\hline $\begin{array}{l}\text { Eastern Mediterranean Sea (Saronikos Gulf and Elefsis Bay } \\
\text { in central Aegean Sea) }\end{array}$ & Greece & 5.2 to 78.2 & (Alygizakis et al., 2016) \\
\hline Atlantic Ocean & Portugal (North and Center, bathing season) & 18 to 525 & Present study \\
\hline
\end{tabular}

analysis but also the detection of others pollutants, e.g., caffeine, pharmaceuticals, and pesticides. This would allow the authorities to act on time and reduce the pollution at its source before pollutants reach the environment.

The highest concentration of caffeine (525 ng/L, sample 78) was found in a beach with water quality classified as sufficient (Table 1). The level of caffeine found in sample 78 allows the confirmation of pollution from human source; however, this was neither consistent with the microbiological results, which were well below the limits $(E$. coli $=15$ NMP and $E$. intestinalis $=15$ NMP (Ttable SM2 (Supplementary material)) nor with the conclusions of the work of Sauvé et al. (2012). However, Ramanavičienè et al. (2003) mentioned that high levels of caffeine affect the growth of $E$. coli. The authors studied the direct effect of caffeine on gram-negative bacterial cultures, and $E$. coli was used as it is widely distributed in the environment. According to the results of Ramanavičienè et al. (2003) and Sauvé et al. (2012), further studies need to be performed to verify the correlation between the levels of caffeine and the microbiological results in water samples.

The average amount of caffeine obtained in the samples collected from the beaches classified as having sufficient water quality is double $(116 \mathrm{ng} / \mathrm{L})$ that of the other two classifications (excellent, $54.9 \mathrm{ng} / \mathrm{L}$ and good, $57.4 \mathrm{ng} / \mathrm{L}$ ) (Table 1). As shown in the box-and-whisker plot in Fig. 3, the interquartile range (range between Q1 and Q3) is higher in samples collected in beaches classified as having sufficient water quality. In all water quality parameters, there are outliers and outlier extremes; however, in the samples collected from beaches classified as having sufficient water quality, the outlier had the highest caffeine concentration. The lowest median caffeine concentration was achieved for the beaches classified as having good water quality, followed by excellent and sufficient water qualities. The lowest caffeine concentration detected in the three water quality classifications was very similar.

The concentration of caffeine found in the samples collected from different beaches was also compared (Table 1). The beaches were numbered from B1 to B14 (Table SM1, Supplementary material). For 
the majority of the beaches, the average amount of caffeine was $<100$ ng/L. The exceptions are beaches B12 (156 ng/L), B13 (136 ng/L), and B9 $(103 \mathrm{ng} / \mathrm{L})$. At those beaches the highest concentration of caffeine was found: $525 \mathrm{ng} / \mathrm{L}$ at B13and $481 \mathrm{ng} / \mathrm{L}$ at B12, both classified as having sufficient water quality, and $336 \mathrm{ng} / \mathrm{L}$ at B9 classified as having good water quality. The highest non-outlier range was observed at B12 (sufficient water quality), followed by B5 (excellent water quality). None of the beaches classified as excellent (B1 to B7) had outliers, and outliers extremes were observed only in beaches classified as having sufficient water quality (B13 and B14) (Fig. 3).

The seasonal bathing period falls during the four months of June, July, August, and September (Table 1). However, it is important to mention that less number of samples were collected in June and September as they were the beginning and end of the bathing season, respectively, and therefore, only half of those months were monitored. The highest average caffeine concentration was found in July, with $86.8 \mathrm{ng} / \mathrm{L}$, followed by August $(77.1 \mathrm{ng} / \mathrm{L})$ and June and September with similar average values of 69.5 and $61.8 \mathrm{ng} / \mathrm{L}$, respectively. The highest caffeine concentration was observed in one sample collected in July (525 ng/L) (Table 1). September showed the highest non-outlier range, the lowest median, and no outliers. June and July showed the lowest non-outlier range, and only outlier extremes were observed in July (Fig. 3).

Samples collected from the beaches of five cities were the target of the present study (Table 1). It was observed that City 3 is undoubtedly the city with the highest average caffeine concentration $(120 \mathrm{ng} / \mathrm{L})$, followed by City $2(106 \mathrm{ng} / \mathrm{L})$. Cities with the lowest population density (Cities 1, 4, and 5) had the lowest average caffeine concentration. The results obtained in those three cities were similar, with caffeine levels of 48.9, 46.4, and $51.5 \mathrm{ng} / \mathrm{L}$, respectively. The highest caffeine concentration $(525 \mathrm{ng} / \mathrm{L})$ was found in one sample collected in the city with the highest population density (City 3). From Fig. 3, it can be observed that all cities had outliers, but only Cities 3, 4, and 5 had outlier extremes. The highest non-outlier range was observed for the two cities with the highest population density (Cities 2 and 3), and the lowest was found for City 1 . The lowest median was observed for City 4 and the highest for City 3. Finally, City 2 has not only the highest interquartile range (range between Q1 and Q3) but also the highest non-outlier range.

Our results were compared with the results published by the scientific community, and the caffeine levels found are present in Table 2. The minimum, maximum, average, and median concentrations of caffeine found in our study were $18.0,525,80.9$, and $48.3 \mathrm{ng} / \mathrm{L}$, respectively (Table 1). The caffeine concentration range found in our study is consistent with the range of caffeine reported in Adriatic Sea (82.0 to $366.9 \mathrm{ng} / \mathrm{L}$ ) (Loos et al., 2013), Barbados West Coast in the tropical Caribbean (100 to $500 \mathrm{ng} / \mathrm{L}$ ) (Edwards et al., 2015), offshore in Kuwait Bay and along the Gulf coastline (40 to $370 \mathrm{ng} / \mathrm{L}$ ) (Smith et al., 2015), and Northeast Aegean Sea (up to 522 ng/L) (Nödler et al., 2016). The concentrations of caffeine obtained in our study are higher than those found in the North Sea (Weigel et al., 2001; Weigel et al., 2002); Mediterranean sea (Buerge et al., 2003; Munaron et al., 2012; Nödler et al., 2014; Alygizakis et al., 2016); Pacific Ocean (Verenitch and Mazumder, 2008; Rodriguez del Rey et al., 2012; Nödler et al., 2014); Balearic Sea (Nödler et al., 2014); in Adriatic Sea (Nödler et al., 2014); Baltic Sea (Nödler et al., 2010); Atlantic Ocean (Hedgespeth et al., 2012; Neng and Nogueira, 2012); North Atlantic/Arctic Ocean (Weigel et al., 2004); sea of Southeastern Taiwan (Jiang et al., 2014); the bay, beaches, and harbor of Florida (Gardinali and Zhao, 2002; Peeler et al., 2006; Singh et al., 2010); San Francisco Bay (Klosterhaus et al., 2013; Alvarez et al., 2014; Nödler et al., 2014); Sarasota Bay (Peeler et al., 2006); Hanalei Bay (Knee et al., 2010); and bay of Stockholm (Magnér et al., 2010) (Table 2). The maximum caffeine level found in our study was lower than the levels found in the remaining studies (Benotti and Brownawell, 2007; Comeau et al., 2008; Wu et al., 2008; Bayen et al., 2013; Nödler et al., 2014; Pereira et al., 2016) (Table 2).

Pereira et al. (2016) found a maximum caffeine concentration of
$648.9 \mathrm{ng} / \mathrm{L}$ in the Brazilian coastal zone. In the Marina Bay of Singapore, Wu et al. (2008) reported a maximum caffeine concentration of $1350 \mathrm{ng} / \mathrm{L}$ in 2008 and Bayen et al. (2013) found $655 \mathrm{ng} / \mathrm{L}$ in 2013. In the Atlantic Ocean in Canada, Comeau et al. (2008) reported a caffeine concentration of $1400 \mathrm{ng} / \mathrm{L}$ in 2008. Nödler et al. (2014) determined $1110 \mathrm{ng} / \mathrm{L}$ in Vernice and $3068 \mathrm{ng} / \mathrm{L}$ in the Aegean Sea and Dardanelles in Greece and Turkey. Benotti and Brownawell (2007) reported the highest levels of caffeine, with $5000 \mathrm{ng} / \mathrm{L}$ in the Jamaica Bay.

To our knowledge, Neng and Nogueira (2012) were the first to report (Costa da Caparica) caffeine as one of the compounds analyzed in a group of pharmaceutical and personal care products in seawater samples collected from Portugal. The author reported that caffeine was detected at a concentration lower than MDL.

Toxicity data for three different trophic levels, namely algae, daphnids, and fish, were collected through a literature search. According to the Technical Guidance Document of the European Commission, risk quotient (RQ) is calculated as the maximum measured environmental concentration to be considered the worst case scenario divided into the predicted no-effect concentration, which is EC50 (concentration of a compound where $50 \%$ of its maximal effect is observed) or LC50 (dose required to kill half the members of a tested population after a specified test duration) value, divided by 1000 in the case short-term toxicity data is used. If RQ is equal or above 1 , there is a potential environmental risk, whereas if $\mathrm{RQ}$ is lower than 1 , it indicates no risk (Thomaidi et al., 2015). The toxicity data, maximum measured concentration, and risk quotients are listed in Table SM3 (Supplementary material). The maximum concentration level of caffeine reported in the study do not pose toxicity risks either for fish or daphnids but can have a possible toxic effect on algae. For the three different trophic levels, Alygizakis et al. (2016) also obtained a possible toxic effect of caffeine on algae.

Caffeine is one of the most widely consumed psychoactive substances in the world as it is consumed daily in coffee, tea, soft drinks, and chocolate. It is also an ingredient in condiments, tobacco, and medications. Therefore, the suitability of caffeine as a chemical marker of surface water pollution was assessed.

In summer, many residents and tourists fill the beaches during the bathing season. The Blue Flag is a symbol of environmental quality that is awarded annually to beaches and recreational ports and marine areas that apply a set of four criteria, namely information and environmental education, water quality, environmental management and equipment, and safety and services. This is the first study in which seawater samples from different beaches classified as having sufficient, good, and excellent water qualities were monitored during the bathing season period. A total of 14 beaches from the middle of June to the middle of September 2013 were sampled. Caffeine was detected in all samples with concentrations ranging from 18 to $525 \mathrm{ng} / \mathrm{L}$. The average caffeine concentration was higher in beaches classified as having sufficient water quality, in beaches in tourist cities, and in samples collected in July and August, the level of caffeine being higher in July.

Risk assessment was performed, and from the three different trophic levels (daphnia, algae, and fish), caffeine did not pose toxicity risks to fish or daphnids but can have a possible toxic effect on algae.

The levels of caffeine found in literature in seawater samples indicate that the concentration of caffeine varies widely according to the location of the sampling site. Several authors mentioned that caffeine is detected in seawater samples because the sea receives WWTP inputs and because of tourist and/or recreational activities in which intentionally or unintentionally sewage is been dumping by ships and tourist boats near the sampling location. Therefore, as Portugal is situated in the coastal area, the tourist/tourist activities should not be careless. Finally, the present study demonstrates the suitability of caffeine as a chemical marker of seawater pollution.

The authors have declared no conflict of interest. 


\section{Acknowledgements}

This work received financial support from the European Union (FEDER funds through COMPETE) and National Funds (FCT, Fundação para a Ciência e Tecnologia) through projects UID/QUI/50006/2013. The authors are greatly indebted to all financing sources.

\section{Appendix A. Supplementary data}

Supplementary data to this article can be found online at http://dx. doi.org/10.1016/j.marpolbul.2017.05.030.

\section{References}

Alvarez, D.A., Maruya, K.A., Dodder, N.G., Lao, W., Furlong, E.T., Smalling, K.L., 2014. Occurrence of contaminants of emerging concern along the California coast (2009-10) using passive sampling devices. Mar. Pollut. Bull. 81, 347-354.

Alygizakis, N.A., Gago-Ferrero, P., Borova, V.L., Pavlidou, A., Hatzianestis, I., Thomaidis, N.S., 2016. Occurrence and spatial distribution of 158 pharmaceuticals, drugs of abuse and related metabolites in offshore seawater. Sci. Total Environ. 541, 1097-1105.

Andreu, V., Gimeno-García, E., Pascual, J.A., Vazquez-Roig, P., Picó, Y., 2016. Presence of pharmaceuticals and heavy metals in the waters of a Mediterranean coastal wetland: potential interactions and the influence of the environment. Sci. Total Environ. 540, 278-286.

APA, 2016. Agência Portuguesa do Ambiente-Portuguese Environment Agency. (Available in): http://www.apambiente.pt/. (Retrieved on 30/09/2016).

Bayen, S., Zhang, H., Desai, M.M., Ooi, S.K., Kelly, B.C., 2013. Occurrence and distribution of pharmaceutically active and endocrine disrupting compounds in Singapore's marine environment: influence of hydrodynamics and physical-chemical properties. Environ. Pollut. 182, 1-8.

Benotti, M.J., Brownawell, B.J., 2007. Distributions of pharmaceuticals in an urban estuary during both dry- and wet-weather conditions. Environ. Sci. Technol. 41, 5795-5802.

Boopathy, R., 2000. Factors limiting bioremediation technologies. Bioresour. Technol. 74, 63-67.

Buerge, I.J., Poiger, T., Müller, M.D., Buser, H.-R., 2003. Caffeine, an anthropogenic marker for wastewater contamination of surface waters. Environ. Sci. Technol. 37, 691-700.

Comeau, F., Surette, C., Brun, G.L., Losier, R., 2008. The occurrence of acidic drugs and caffeine in sewage effluents and receiving waters from three coastal watersheds in Atlantic Canada. Sci. Total Environ. 396, 132-146.

Daneshvar, A., Aboulfadl, K., Viglino, L., Broséus, R., Sauvé, S., Madoux-Humery, A.-S., Weyhenmeyer, G.A., Prévost, M., 2012. Evaluating pharmaceuticals and caffeine as indicators of fecal contamination in drinking water sources of the Greater Montreal region. Chemosphere 88, 131-139.

EC, European Comission, 2015. European Bathing Water Quality in 2015. (Available in). http://www.eea.europa.eu/publications/european-bathing-water-quality-2015 (Retrieved on 01/02/2017).

EC, European Commission, 2002. Directive 2002/657/EC. Commission decision of 12 August 2002 implementing council directive 96/23/EC concerning the performance of analytical methods and the interpretation of results. Off. J. Eur. Commun. L221, 8-36.

EC, European Commission, 2006. In: Union, E (Ed.), Directive 2006/7/EC of the European Parliament and of the Council of 15 February 2006 Concerning the Management of Bathing Water Quality and Repealing Directive 76/160/EEC. Official Journal of the European Union.

Edwards, Q.A., Kulikov, S.M., Garner-O'Neale, L.D., 2015. Caffeine in Surface and Wastewaters in Barbados, West Indies. SpringerPlus, Open Journal.

Ferreira, A.P., 2005. Caffeine as an environmental indicator for assessing urban aquatic ecosystems. Cad. Saude Publica 21, 1884-1892.

Ferreira, A.P., da Cunha, C.D.L.N., 2005. Anthropic pollution in aquatic environment: Development of a caffeine indicator. Int. J. Environ. Health Res. 15, 303-311.

Gardinali, P.R., Zhao, X., 2002. Trace determination of caffeine in surface water samples by liquid chromatography-atmospheric pressure chemical ionization-mass spectrometry (LC-APCI-MS). Environ. Int. 28, 521-528.

Gaw, S., Thomas, K.V., Hutchinson, T.H., 2013. Sources, impacts and trends of pharmaceuticals in the marine and coastal environment. Philos. Trans. R. Soc., B 369, $1-11$.

Glassmeyer, S.T., Furlong, E.T., Kolpin, D.W., Cahill, J.D., Zaugg, S.D., Wener, S.L., Meyer, M.T., Kryak, D.D., 2005. Transport of chemical and microbial compounds from known wastewater discharges: potential for use as indicators of human fecal contamination. Environ. Sci. Technol. 39, 5157-5169.

Gokulakrishnan, S., Chandraraj, K., Gummadi, S.N., 2005. Microbial and enzymatic methods for the removal of caffeine. Enzym. Microb. Technol. 37, 225-232.

Gros, M., Rodríguez-Mozaz, S., Barceló, D., 2012. Fast and comprehensive multi-residue analysis of a broad range of human and veterinary pharmaceuticals and some of their metabolites in surface and treated waters by ultra-high-performance liquid chromatography coupled to quadrupole-linear ion trap tandem mass spectrometry. J. Chromatogr. A 1248, 104-121.

Hedgespeth, M.L., Sapozhnikov, Y., Pennington, P., Clum, A., Fairey, A., Wirth, E., 2012.
Pharmaceuticals and personal care products (PPCPs) in treated wastewater discharges into Charleston Harbor, South Carolina. Sci. Total Environ. 437, 1-9.

INE, Instituto Nacional de Estatística, 2013. (Available in). www.ine.pt (Retrieved on 26/ 09/2016).

ISO 5667-3, 2012. Water Quality-Sampling-Part 3: Preservation and Handling of Water Samples.

Jiang, J.-J., Lee, C.-L., Fang, M.-D., 2014. Emerging organic contaminants in coastal waters: anthropogenic impact, environmental release and ecological risk. Mar. Pollut. Bull. 85, 391-399.

Klosterhaus, S.L., Grace, R., Hamilton, M.C., Yee, D., 2013. Method validation and reconnaissance of pharmaceuticals, personal care products, and alkylphenols in surface waters, sediments, and mussels in an urban estuary. Environ. Int. 54, 92-99.

Knee, K.L., Gossett, R., Boehm, A.B., Paytan, A., 2010. Caffeine and agricultural pesticide concentrations in surface water and groundwater on the north shore of Kauai (Hawaii, USA). Mar. Pollut. Bull. 60, 1376-1382.

Kurissery, S., Kanavillil, N., Verenitch, S., Mazumder, A., 2012. Caffeine as an anthropogenic marker of domestic waste: a study from Lake Simcoe watershed. Ecol. Indic. 23, 501-508.

Leeming, R., Nichols, P.D., 1996. Concentrations of coprostanol that correspond to existing bacterial indicator guideline limits. Water Res. 30, 2997-3006.

Lolić, A., Paíga, P., Santos, L.H.M.L.M., Ramos, S., Correia, M., Delerue-Matos, C., 2015 Assessment of non-steroidal anti-inflammatory and analgesic pharmaceuticals in seawaters of North of Portugal: occurrence and environmental risk. Sci. Total Environ. 508, 240-250.

Loos, R., Tavazzi, S., Paracchini, B., Canuti, E., Weissteiner, C., 2013. Analysis of polar organic contaminants in surface water of the northern Adriatic Sea by solid-phase extraction followed by ultrahigh-pressure liquid chromatography-QTRAP(A (R)) MS using a hybrid triple-quadrupole linear ion trap instrument. Anal. Bioanal. Chem. 405, 5875-5885.

Magnér, J., Filipovic, M., Tomas, A., 2010. Application of a novel solid-phase-extraction sampler and ultra-performance liquid chromatography quadrupole-time-of-flight mass spectrometry for determination of pharmaceutical residues in surface sea water. Chemosphere 80, 1255-1260.

McLella, S.L., Eren, A.M., 2014. Discovering new indicators of fecal pollution. Trends Microbiol. 22, 697-706.

Munaron, D., Tapie, N., Budzinski, H., Andral, B., Gonzalez, J.-L., 2012. Pharmaceuticals, alkylphenols and pesticides in Mediterranean coastal waters: results from a pilot survey using passive samplers. Estuar. Coast. Shelf Sci. 114, 82-92.

Neng, N.R., Nogueira, J.M.F., 2012. Development of a bar adsorptive microextraction-large-volume injection-gas chromatography-mass spectrometric method for pharmaceuticals and personal care products in environmental water matrices. Anal. Bioanal. Chem. 402, 1355-1364.

Nödler, K., Licha, T., Bester, K., Sauter, M., 2010. Development of a multi-residue analytical method, based on liquid chromatography-tandem mass spectrometry, for the simultaneous determination of 46 micro-contaminants in aqueous samples. J. Chromatogr. A 1217, 6511-6521.

Nödler, K., Voutsa, D., Licha, T., 2014. Polar organic micropollutants in the coastal environment of different marine systems. Mar. Pollut. Bull. 85, 50-59.

Nödler, K., Tsakiri, M., Aloupi, M., Gatidou, G., Stasinakis, A.S., Licha, T., 2016. Evaluation of polar organic micropollutants as indicators for wastewater-related coastal water quality impairment. Environ. Pollut. 211, 282-290.

Paíga, P., Delerue-Matos, C., 2016. A throughput method using the quick easy cheap effective rugged safe method for the quantification of ibuprofen and its main metabolites in soils. J. Sep. Sci. 39, 3436-3444.

Paíga, P., Lolić, A., Hellebuyck, F., Santos, L., Correia, M., Delerue-Matos, C., 2015. Development of a SPE-UHPLC-MS/MS methodology for the determination of nonsteroidal anti-inflammatory and analgesic pharmaceuticals in seawater. J. Pharmaceut. Biomed. Anal. 106, 61-70.

Peeler, K.A., Opsahl, S.P., Chanton, J.P., 2006. Tracking anthropogenic inputs using caffeine, indicator bacteria, and nutrients in rural freshwater and urban marine systems. Environ. Sci. Technol. 40, 7616-7622.

Pereira, C.D.S., Maranho, L.A., Cortez, F.S., Pusceddu, F.H., Santos, A.R., Ribeiro, D.A., Cesar, A., Guimarães, L.L., 2016. Occurrence of pharmaceuticals and cocaine in a Brazilian coastal zone. Sci. Total Environ. 548-549, 148-154.

Ramanavičienè, A., Mostovojus, V., Bachmatova, I., Ramanavičius, A., 2003. Antibacterial effect of caffeine on Escherichia coli and Pseudomonas fluorescens. ACTA Med. Lituanica 4, 185-188.

Reis, P., Jorge, J.P., 2012. Surf Tourism: Segmentation by Motivation and Destination Choice. In: Proceedings of the 2nd International Conference on Tourism Recreation, 7th to 9th November 2012. ESTM, Peniche.

Ribeiro, C., Ribeiro, A.R., Tiritan, M.E., 2015. Reviews of environmental contamination and toxicology, continuation of residue reviews. In: Priority Substances and Emerging Organic Pollutants in Portuguese Aquatic Environment: A Review. Springer.

Rodriguez del Rey, Z., Granek, E.F., Sylvester, S., 2012. Occurrence and concentration of caffeine in Oregon coastal waters. Mar. Pollut. Bull. 64, 1417-1424.

Sauvé, S., Aboulfadl, K., Dorner, S., Payment, P., Deschamps, G., Prévost, M., 2012. Fecal coliforms, caffeine and carbamazepine in stormwater collection systems in a large urban area. Chemosphere 86, 118-123.

Siegener, R., Chen, R.F., 2002. Caffeine in Boston Harbor seawater. Mar. Pollut. Bull. 44, 383-387.

Singh, S.P., Azua, A., Chaudhary, A., Khan, S., Willett, K.L., Gardinali, P.R., 2010. Occurrence and distribution of steroids, hormones and selected pharmaceuticals in South Florida coastal environments. Ecotoxicology 19, 338-350.

Smith, A.J., McGowan, T., Devlin, M.J., Massoud, M.S., Al-Enezi, M., Al-Zaidan, A.S., Al Sarawi, H.A., Lyons, B.P., 2015. Screening for contaminant hotspots in the marine environment of Kuwait using ecotoxicological and chemical screening techniques. 
Mar. Pollut. Bull. 100, 681-688.

Surf Today, n.d. Surfing in Portuguese Northern Coast. (Available in): www.surfertoday. $\mathrm{com} /$ travel/12411-the-truth-about-surfing-in-portugals-northern-coast. (Retrieved on $26 / 09 / 2016$ ).

Thomaidi, V.S., Stasinakis, A.S., Borova, V.L., Thomaidis, N.S., 2015. Is there a risk for the aquatic environment due to the existence of emerging organic contaminants in treated domestic wastewater? Greece as acase-study. J. Hazard. Mater. 283, 740-747.

Tourism in Portugal, n.d. (Available in): www.travelweekly.com/Europe-Travel/Insights/ Portugal-makes-a-tourism-comeback. (Retrieved on 26/09/2016).

Verenitch, S.S., Mazumder, A., 2008. Development of a methodology utilizing gas chromatography ion-trap tandem mass spectrometry for the determination of low levels of caffeine in surface marine and freshwater samples. Anal. Bioanal. Chem. 391, 2635-2646.

Weigel, S., Bester, K., Huhnerfuss, H., 2001. New method for rapid solid-phase extraction of large-volume water samples and its application to non-target screening of North Sea water for organic contaminants by gas chromatography-mass spectrometry. J. Chromatogr. A 912, 151-161.

Weigel, S., Kuhlmann, J., Huhnerfuss, H., 2002. Drugs and personal care products as ubiquitous pollutants: occurrence and distribution of clofibric acid, caffeine and DEET in the North Sea. Sci. Total Environ. 295, 131-141.

Weigel, S., Berger, U., Jensen, E., Kallenborn, R., Thoresen, H., Hühnerfuss, H., 2004 Determination of selected pharmaceuticals and caffeine in sewage and seawater from Troms $\varnothing /$ Norway with emphasis on ibuprofen and its metabolites. Chemosphere 56, 583-592.

Wu, J., Yue, J., Hu, R., Yang, Z., Zhang, L., 2008. Use of Caffeine and Human Pharmaceutical Compounds to Identify Sewage Contamination. World Academy of Science, Engineering and Technology International Journal of Medical, Health, Biomedical, Bioengineering and Pharmaceutical Engineering Volume 2, Number 8. 